\title{
Chemo-Enzymatic Synthesis of Antagonists of the Myelin-associated Glycoprotein (MAG)
}

\author{
Gan-Pan Gao*, Oliver Schwardt, Tamara Visekruna, Said Rabbani, and Beat Ernst
}

\begin{abstract}
Ganglioside GQ1bo is the most potent antagonist of the Myelin-associated glycoprotein (MAG) identified so far. For the efficient synthesis of the partial structure of GQ1b $\alpha$ and derivatives thereof, a chemo-enzymatic strategy using the $\alpha(2 \rightarrow 3)$-sialyltransferase ratST3Gal III (EC 2.4.99.6) was applied. Besides the natural substrates Gal $\beta(1 \rightarrow 3)$ GlcNAc (19) and Gal $\beta(1 \rightarrow 4)$ GlcNAc $(20)$, the disaccharides Gal $\beta(1 \rightarrow 3)$ GalNTCA $\beta$-OSE (9), Gal $\beta(1 \rightarrow 3)$ GalNAc $\beta$-OSE (11), and Gal $\beta(1 \rightarrow 3)$ Gal $\beta$-OSE (14) were also tolerated by the enzyme and were transformed to the target structures in preparative scale.
\end{abstract}

Keywords: Chemo-enzymatic synthesis · Myelin-associated glycoprotein (MAG) · ratST3Gal III · $\alpha(2 \rightarrow 3)$-Sialyltransferase

\section{Introduction}

Axons of the adult mammalian central nervous system (CNS) do not regenerate after injury, largely due to inhibitors in the myelin sheath, an insulator that wraps around axons [1]. To date, the myelin-associated glycoprotein (MAG) [2] has been identified as one of the neurite outgrowthinhibitory proteins, together with Nogo-A and the oligodendrocyte myelin glycoprotein $(\mathrm{OMgp})$ [3]. All of them bind to the same receptor $\mathrm{NgR}$, which interacts with p $75^{\text {NTR }}$ to transduce the inhibitory signal across the membrane (Fig. 1) [4]. In addition, MAG - the only member of the siglec (sialic acid binding immunoglobulin lectin) family in the mammalian CNS - was found to bind with high specificity and affinity to brain gangliosides like GT1b, GD1a and GQ1b $\alpha[5]$.

\footnotetext{
${ }^{*}$ Correspondence: G.-P. Gao

University of Basel

Institute of Molecular Pharmacy

Klingelbergstrasse 50

$\mathrm{CH}-4056$ Basel

Tel.: +41612671557

Fax: +41612671552

E-Mail: Ganpan.Gao@unibas.ch
}

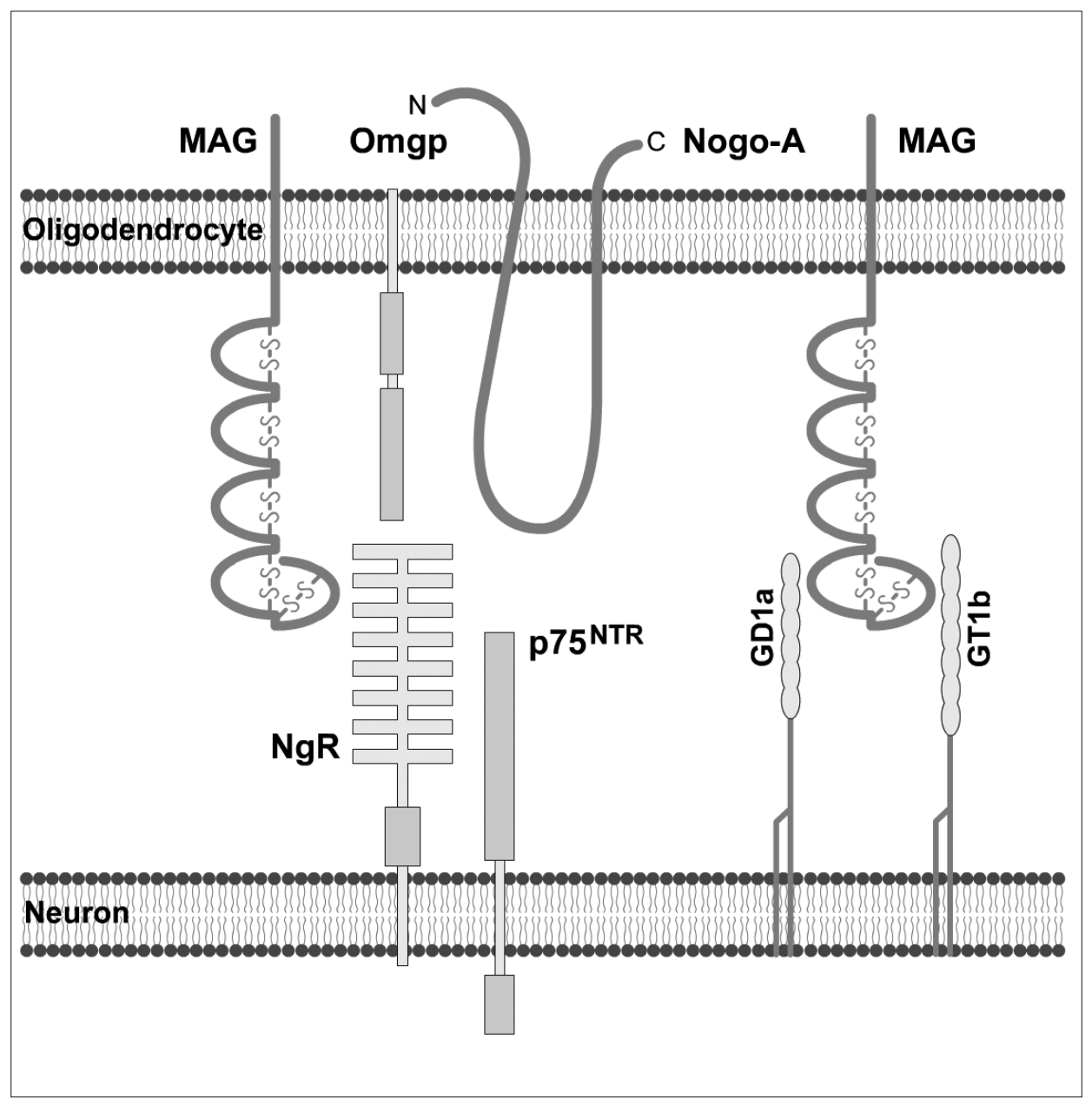

Fig. 1. Myelin-associated inhibitors of axonal regeneration in the adult mammalian CNS 


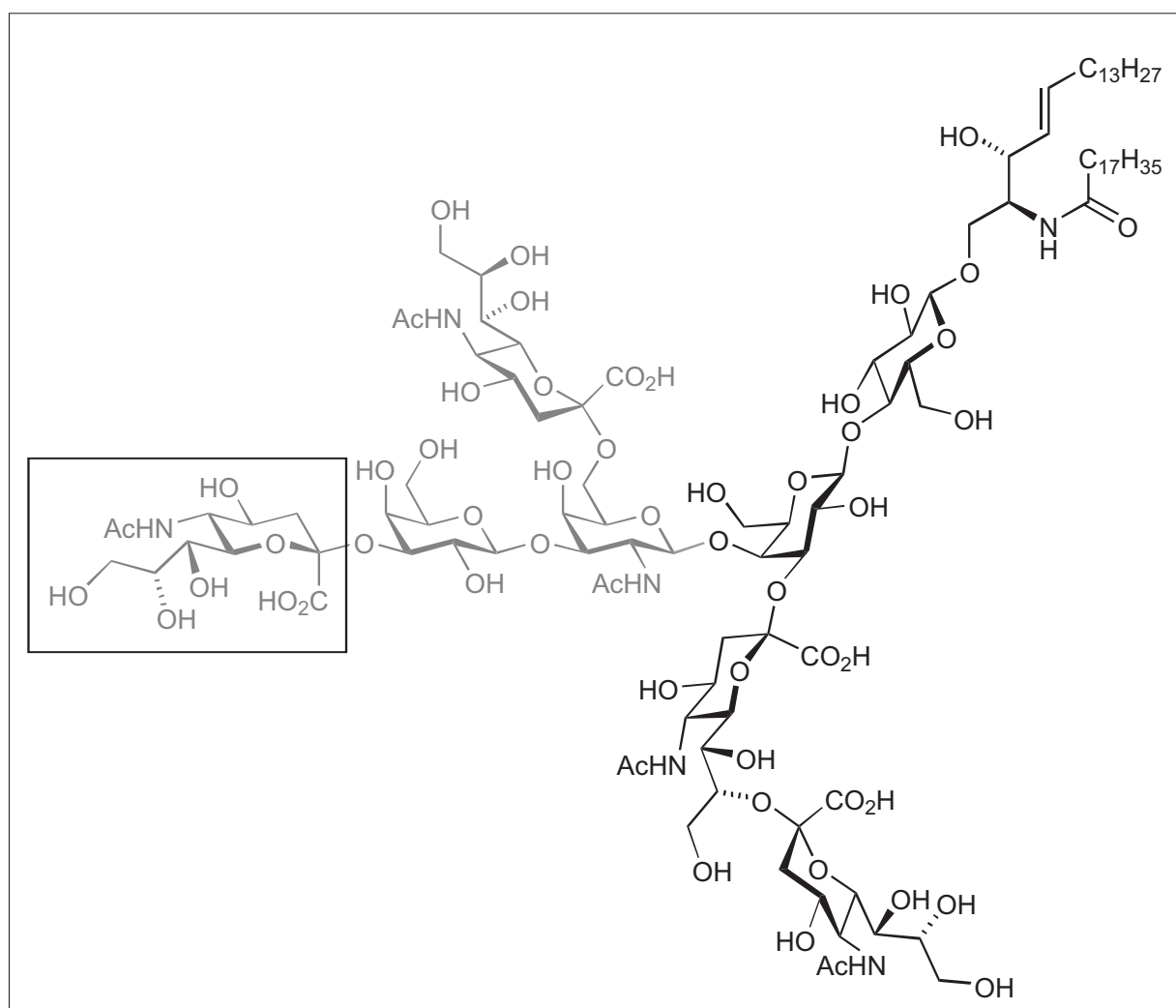

Fig. 2. The ganglioside GQ1b $\alpha$

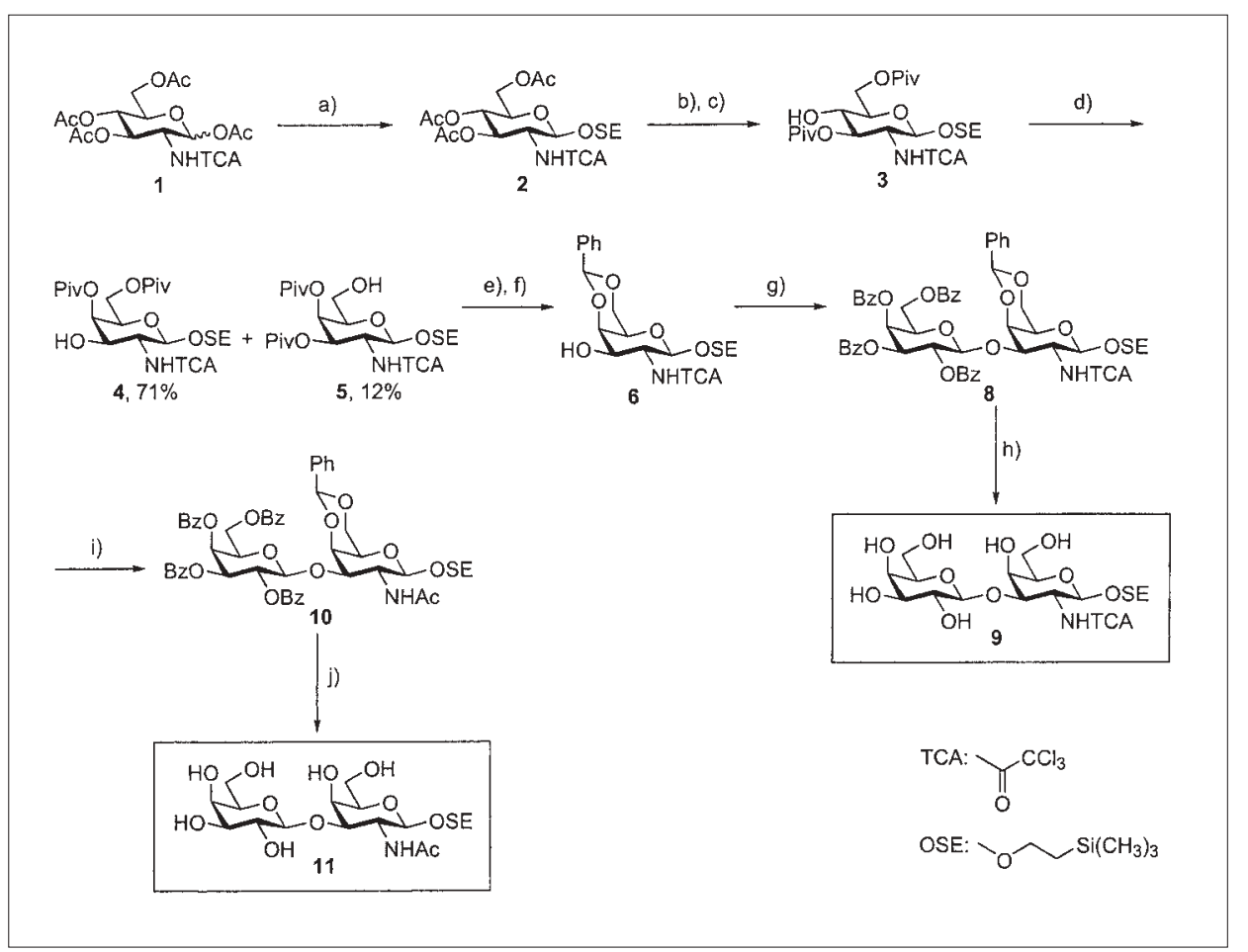

Scheme 1. a) i. $\mathrm{HBr} / \mathrm{AcOH}$, rt, $17 \mathrm{~h}$, ii. $\mathrm{HOSE}, \mathrm{Hg}(\mathrm{CN})_{2}$, MS $3 \AA$, toluene, rt, $3 \mathrm{~d}(89 \%)$; b) cat. $\mathrm{NaOMe} / \mathrm{MeOH}, \mathrm{rt}, 16 \mathrm{~h}$ (quant); c) 2.5 equiv. PivCl, cat. DMAP, pyridine, $\left.-30{ }^{\circ} \mathrm{C}, 20 \mathrm{~h}(89 \%) ; \mathrm{d}\right) \mathrm{Tf}_{2} \mathrm{O}$, DCE/pyridine 2:1, $0{ }^{\circ} \mathrm{C}, 4 \mathrm{~h}$, then $\mathrm{H}_{2} \mathrm{O}, 80^{\circ} \mathrm{C}, 2 \mathrm{~h}(83 \%)$; e) $0.1 \mathrm{M} \mathrm{NaOMe} / \mathrm{MeOH}, \mathrm{rt}, 7 \mathrm{~h},(96 \%) ;$ f) $\mathrm{PhCH}(\mathrm{OMe})_{2}$, cat. $p$-TsOH, MeCN, it, $4 \mathrm{~h}(86 \%)$; g) ethyl 2,3,4,6-tetra-O-benzoyl-1-thio- $\beta$-D-galactopyranoside (7), NIS, TfOH, $\mathrm{CH}_{2} \mathrm{Cl}_{2},-25^{\circ} \mathrm{C}, 1.5$ d (64\% $\left.\beta\right)$; h) i. cat. $\mathrm{NaOMe} / \mathrm{MeOH}$, rt, 18 h, ii. $80 \%$ aq. $\mathrm{AcOH}, 80^{\circ} \mathrm{C}, 2 \mathrm{~h}(46 \%)$; i) $\mathrm{Bu}_{3} \mathrm{SnH}, \mathrm{AlBN}$, benzene, $80^{\circ} \mathrm{C}, 3 \mathrm{~h}(93 \%)$; j) i. $80 \%$ aq. $\mathrm{AcOH}, 50^{\circ} \mathrm{C}$, $4.5 \mathrm{~h}$, ii. cat. $\mathrm{NaOMe} / \mathrm{MeOH}, \mathrm{rt}, 21 \mathrm{~h}(64 \%)$.
The ganglioside GQ1ba (Fig. 2), which is the most potent MAG antagonist identified so far [5], consists of an octasaccharide and a ceramide at its reducing end. Based on a structure-activity relationship (SAR) study with numerous glycosphingolipids, the branched tetrasaccharide Neu5Aco$(2 \rightarrow 3) \mathrm{Gal} \beta(1 \rightarrow 3)[\mathrm{Neu} 5 \mathrm{Ac} \alpha(2 \rightarrow 6)] \mathrm{Gal} N$ Ac (Fig. 2, in grey) was found to make the major contribution to MAG-binding, whereas the $\alpha(2 \rightarrow 3)$-linked sialic acid residue (Fig. 2, in box) was a prerequisite for affinity [5].

For a refined SAR study, we decided to synthesize modified sialylated oligosaccharides. Despite considerable recent progress [6], the stereoselective synthesis of $\alpha$-sialosides by chemical sialylation remains a significant challenge due to the sterically hindered tertiary anomeric centre, the presence of an electron-withdrawing carboxylate and the lack of a participating neighbouring group in the 3-position of the sialic acid moiety [7]. Enzymatic syntheses employing sialyltransferases as biocatalysts offer an alternative approach to sialylated oligosaccharides with excellent stereoselectivity and generally good to excellent yields [8].

Previous studies showed that the $\alpha(2 \rightarrow 3)$-sialyltransferases ST3Gal I [9], II $[10]$, and $I V[11]$ are the physiological enzymes which transfer sialic acid residues to the 3-OH group of the terminal galactose moiety of the type III disaccharide $\operatorname{Gal} \beta(1 \rightarrow 3)$ GalNAc. The natural substrates of ST3Gal III [12], however, are type I $[\mathrm{Gal} \beta(1 \rightarrow 3) \mathrm{GlcNAc}]$ and type II $[\mathrm{Gal} \beta(1 \rightarrow 4) \mathrm{GlcNAc}]$ disaccharides. In addition, it was shown that ST3Gal III accepts a wide variety of substituents on the glucosamine nitrogen [8b], as well as lactal, lactose and 2-O-pivaloyllactose [13]. Here, we report that ratST3Gal III (EC 2.4.99.6) can also be used for the enzymatic synthesis of partial structure of GQ1b $\alpha$ and derivatives thereof.

\section{Results and Discussion}

The type III substrates $\mathrm{Gal} \beta(1 \rightarrow 3) \mathrm{Gal} N$ and $\operatorname{Gal} \beta(1 \rightarrow 3)$ Gal were chemically synthesized as shown in Schemes 1 and 2 [14]. By using the trichloroacetyl (TCA) protecting group, $\operatorname{Gal} \beta(1 \rightarrow 3)$ GalNTCA $\beta$-OSE (9) and $\operatorname{Gal} \beta(1 \rightarrow 3)$ GalNAc $\beta-O S E$ (11) could easily be obtained (Scheme 1).

For this purpose, per-O-acetylated Ntrichloroacetylglucosamine (1) [15] was transferred into the (trimethylsilyl)ethyl glycoside 2 via the corresponding bromide. Subsequent O-deacetylation and selective 3,6-O-bis-pivaloylation gave $\mathbf{3}$ in $89 \%$ yield. After transformation of the 4-hydroxy group into the corresponding triflate, the galactosamides $\mathbf{4}$ and $\mathbf{5}$ were obtained in 


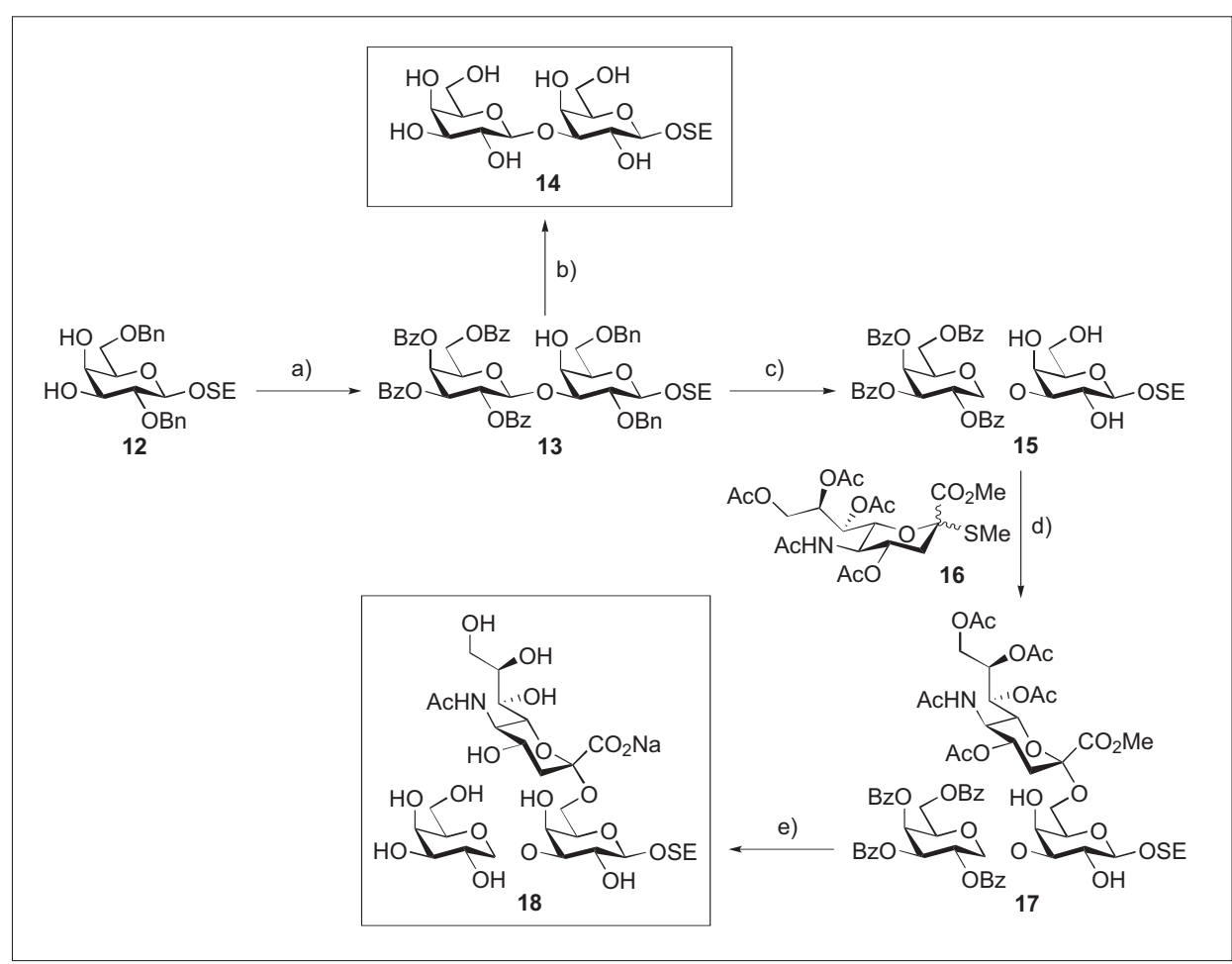

Scheme 2. a) 7, DMTST, $\mathrm{CH}_{2} \mathrm{Cl}_{2}, 7^{\circ} \mathrm{C}, 16 \mathrm{~h}\left(87 \%\right.$ ) ; b) i. $\mathrm{NaOMe}, \mathrm{MeOH}, \mathrm{rt}, 2 \mathrm{~h}$, ii. $10 \% \mathrm{Pd} / \mathrm{C}, \mathrm{H}_{2}$ $\mathrm{MeOH}$, rt, $3 \mathrm{~h}\left(75 \%\right.$ ); c) $10 \% \mathrm{Pd} / \mathrm{C}, \mathrm{H}_{2}$ (4 bar), $\mathrm{MeOH} /$ dioxane, rt, $9 \mathrm{~d}$ (67\%); d) 16, NIS, TfOH, $\mathrm{CH}_{2} \mathrm{Cl}_{2}$, $-30{ }^{\circ} \mathrm{C}, 16 \mathrm{~h}(45 \% \alpha)$; e) $\mathrm{NaOMe}, \mathrm{MeOH}, \mathrm{rt}, 7 \mathrm{~h}$, then aq. $\mathrm{NaOH}, \mathrm{rt}, 16 \mathrm{~h}(90 \%)$.

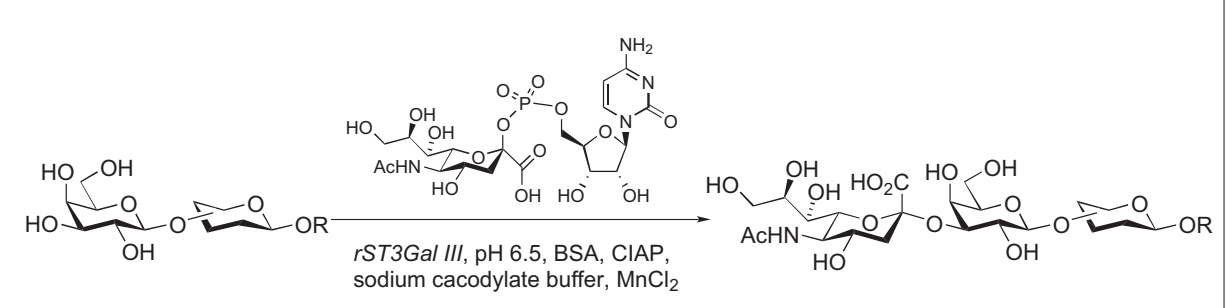

Scheme 3. Enzymatic sialidation using rST3Gal III and CMP-Neu5Ac

a 6:1 ratio by epimerization at $80^{\circ} \mathrm{C}$. By transesterification, the pivaloates were removed and the 4- and 6-OHs were protected as benzylidene $(\rightarrow \mathbf{6})$. The subsequent coupling reaction with donor 7 [16] was carried out using NIS/TfOH [17] as promotor, resulting in pure $\beta$-disaccharide 8 in $64 \%$ yield. Removal of the benzoyl groups and subsequent cleavage of the benzylidene group gave $\operatorname{Gal} \beta(1 \rightarrow 3) \mathrm{Gal} N \mathrm{TCA} \beta$-OSE (9) in $46 \%$ yield. From 8, Gal $\beta(1 \rightarrow 3)$ GalNAc $\beta$-OSE (11) was obtained by reduction of the $\mathrm{N}$ trichloroacetyl group with $\mathrm{Bu}_{3} \mathrm{SnH} / \mathrm{AIBN}$ in refluxing benzene $(\rightarrow \mathbf{1 0})$, followed by $\mathrm{O}$ debenzoylation $(\rightarrow \mathbf{1 1})$.

The other two starting materials for the enzymatic sialylation experiments, $\operatorname{Gal} \beta(1 \rightarrow 3)$ Gal $\beta$-OSE $(\mathbf{1 4})$ and $\mathrm{Gal} \beta(1 \rightarrow 3)$ $[\mathrm{Neu} 5 \mathrm{Ac} \alpha(2 \rightarrow 6)] \mathrm{Gal} \beta$-OSE (18), were synthesized starting from the galactose de- rivative 12 [18] (Scheme 2). For this purpose, 12 was coupled with donor 7 using dimethyl(methylthio)sulfonium triflate (DMTST) [19] as promoter to afford $\mathbf{1 3}$ in excellent yield and stereoselectivity. After removal of the benzoyl and benzyl protecting groups by transesterification and hydrogenolysis respectively, $\operatorname{Gal} \beta(1 \rightarrow 3)$ Gal $\beta$-OSE (14) was isolated in $75 \%$ yield. 18 was obtained starting from 13, which was partially deprotected by catalytic hydrogenation $(\rightarrow \mathbf{1 5})$, followed by coupling with the sialic acid donor 16 [20] in the presence of NIS/TfOH affording the corresponding $\alpha$-sialoside 17 in $45 \%$ yield. Subsequent saponification gave trisaccharide 18 in $90 \%$.

Following our standard sialylation protocol [12][21], the oligosaccharides $\mathbf{9}, \mathbf{1 1}$, 14 and $\mathbf{1 8}$, and, as positive controls, the nat- ural substrates $\mathbf{1 9}$ [22][23] and 20 [23][24] were then incubated with cytidine-5'monophospho-N-acetylneuraminic acid (CMP-Neu5Ac) and recombinant $r S T 3 G a l$ III (9 U/L) (Scheme 3$)$ in preparative scale [14]. After 17-24 h of incubation, one additional aliquot of transferase was added (except for the natural substrates 19 and 20). The addition of another aliquot of $r S T 3 \mathrm{Gal}$ III and CMP-Neu5Ac did not further increase the yields.

The natural substrates 19 (type I) and $\mathbf{2 0}$ (type II) were converted quantitatively into the corresponding trisaccharides $\mathbf{2 1}$ and $\mathbf{2 2}$ [12] (entries 1 and 2 in the Table). In addition, the disaccharides $\mathbf{9 , 1 1}$ and $\mathbf{1 4}$ were also sialylated by rST3Gal III affording the corresponding trisaccharides $\mathbf{2 3 - 2 5}$ in acceptable yields (entries 3-5, Table). In all three cases, the unreacted substrates could be recovered almost quantitatively. The kinetic data for the sialylation reactions indicate that the activity of $r S T 3 \mathrm{Gal} \mathrm{III} \mathrm{towards}$ the substrates 9, 11 and $\mathbf{1 4}$ is reduced about 10 -fold compared to the one for its natural substrates 19 and 20. As expected, also the transfer efficiency $\mathrm{V}_{\text {max }} / \mathrm{K}_{\mathrm{m}}$ is much lower for the unnatural substrates. This explains the incomplete, but still preparatively useful conversion of the type III disaccharides. Probably, due to the bulky substituent in the 6-position of galactose, the 6-O-sialylated trisaccharide $\mathbf{1 8}$ was not tolerated as substrate by $r$ ST3Gal III.

The introduction of a sialic acid unit was indicated by signals in ${ }^{13} \mathrm{C}$ NMR at approximately $100 \mathrm{ppm}$ and $40 \mathrm{ppm}$, which are characteristic for the $\mathrm{C}(2)$ and $\mathrm{C}(3)$ of an $\alpha$-linked sialic acid [12][13][24]. In addition, down-field shifts ( $4 \mathrm{ppm})$ of the galactose $\mathrm{C}(3)$ in ${ }^{13} \mathrm{C}$ NMR and approximately $0.6 \mathrm{ppm}$ of the galactose $\mathrm{H}(3)$ in ${ }^{1} \mathrm{H}$ NMR confirmed the regioselective introduction of sialic acid in the 3-position of the galactose moiety [12].

\section{Conclusion}

The MAG antagonists 23, 24, and 25 were prepared by the chemical synthesis of the type III disaccharides $\mathbf{9 , 1 1}$, and $\mathbf{1 4}$, and subsequent enzymatic sialylation using rST3Gal III for the transfer of sialic acid from CMP-Neu5Ac. The determination of the MAG affinity in comparison with GQ1bo is currently ongoing.

\section{Acknowledgements}

We thank Markus Streiff (Novartis Pharma Inc., Basel) for supplying us with the $r S T 3 G a l$ III construct. Financial support by the Volkswagen Stiftung is kindly acknowledged.

Received: February 5, 2004

[1] a) A.R. Johnson, BioEssays 1993, 15, 807-813; b) M.E. Schwab, J.P. Kapfham- 
Table. Isolated yields and kinetic data of the enzymatic sialidations ${ }^{a}$

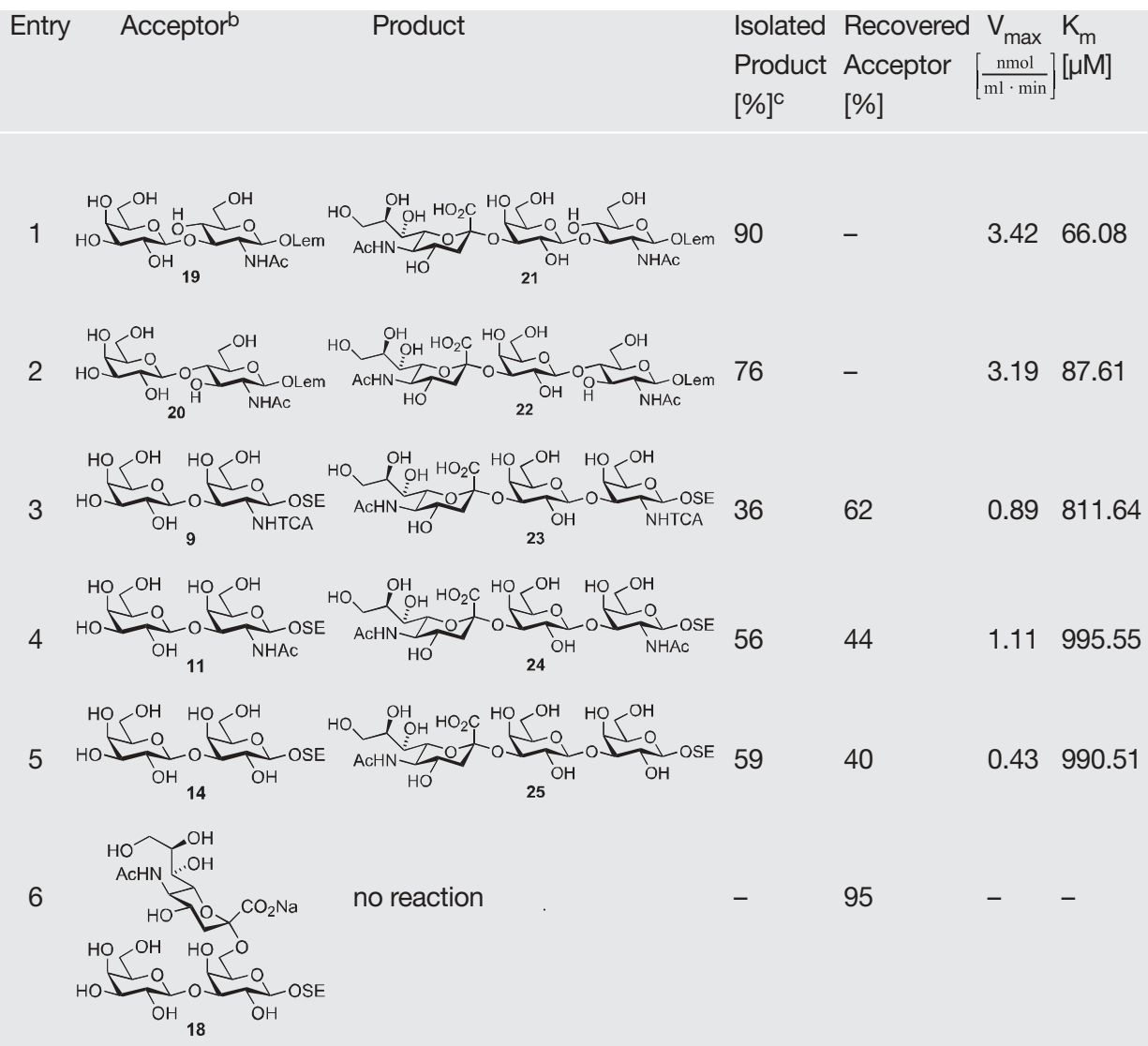

aSubstrates and CMP-Neu5Ac were incubated with rST3Gal III for $3-5 \mathrm{~d}$ at $37^{\circ} \mathrm{C}$ in a mixture of $50 \mathrm{mM}$ sodium cacodylate buffer ( $\mathrm{pH} 6.5), 60 \mathrm{mM} \mathrm{MnCl}_{2}$-solution and water containing BSA and $\operatorname{CIAP}$ (EC 3.1.3.1); b. 19, 20: $3 \mathrm{mg}, 9,11,14,18: ~ 10 \mathrm{mg}$; c. The course of the reactions was monitored by TLC (silica gel, DCM/MeOH/ $\left.\mathrm{H}_{2} \mathrm{O} 10: 4: 0.8\right)$. Isolated yields, recovered starting material and kinetic data $\left(\mathrm{V}_{\max }\right.$ and $\left.\mathrm{K}_{\mathrm{m}}\right)$ are summarized in the Table [14]

mer, C.E. Bandtlow, Annu. Rev. Neurosci. 1993, 16, 565-595.

[2] a) L. Mckerracher, S. David, D.L. Jackson, V. Kottis, R.J. Dunn, P.E. Braun, Neuron 1994, 13, 805-811; b) G. Mukhopadhyay, P. Doherty, F.S. Walsh, P.R. Crocker, M.T. Filbin, Neuron 1994, 13, 757-767; c) M.E. DeBellard, S. Tang, G. Mukhopadhyay, Y.J. Shen, M.T. Filbin, Mol. Cell. Neusci. 1996, 7, 89-101; d) Y.J. Shen, M.E. DeBellard, J.L. Salzer, J. Roder, M.T. Filbin, Mol. Cell. Neusci. 1998, 12, 79-91.

[3] a) C.J. Woolf, S. Bloechlinger, Science 2002, 297, 1132-1134; b) M. T. Filbin, Nat. Rev. Neurosci. 2003, 4, 1-11; c) T. Spencer, M. Domeniconi, Z.X. Cao, M.T. Filbin, Curr. Opin. Neurobiol. 2003, 13, 133-139.

[4] G. Yiu, Z. He, Curr. Opin. Neurobiol. 2003, 13, 545-551.

[5] a) L.S. Yang, C.B. Zeller, N.L. Shaper, M. Kiso, A. Hasegawa, R.E. Shapiro, R.L. Schnaar, Proc. Natl. Acad. Sci. USA 1996, 93, 814-818; b) A.A. Vyas, H.V. Patel, S.E. Fromholt, M. Heffer-Lauc, K.A. Vyas, J. Dang, M. Schachner, R.L. Schnaar, Proc. Natl. Acad. Sci. USA 2002, 99, 8412-8417.

[6] a) A. Hasegawa, H. Ohki, T. Nagahama, H. Ishida, M. Kios, Carbohydr. Res. 1991 ,
212,277-281; b) A. Marra, P. Sinay, Carbohydr. Res. 1990, 195, 303-308; c) T.J. Martin, R.R. Schmidt, Tetrahedron Lett. 1992, 33, 6123-6126; d) H. Kondo, Y. Ichikawa, C.H. Wong, J. Am. Chem. Soc. 1992, 114, 8748-8750; e) A.V. Demchenko, G.J. Boons, Chem. Eur. J. 1999 , 5(4), 1278-1283; f) C.D. Meo, A.V. Demchenko, G.J. Boons, J. Org. Chem. 2001 66, 5490-5497.

[7] a) K. Okamoto, T. Goto, Tetrahedron 1990, 46, 5835-5857; b) G.J. Boons, A.V. Demchenko, Chem. Rev. 2000, 100, 4539-4565.

[8] a) H.J.M. Gijsen, L. Qiao, W. Fitz, C.H. Wong, Chem. Rev. 1996, 96, 443-473; b) X.P. Qian, K. Sujino, M.M. Palcic, in 'Carbohydrates in Chemistry and Biology', Eds. B. Ernst, G.W. Hart, P. Sinaÿ, Wiley-VCH, Weinheim, 2000, 2, p. 685-704; c) R Öhrlein, Topics Curr. Chem. 1999, 200, 227-254; d) B. Ernst, R. Öhrlein, Glycoconjugate J. 1999, 16, 161-170.

[9] a) H. Kitagawa, J.C. Paulson, J. Biol. Chem. 1994, 269, 17872-17878; b) Y.C. Lee, N. Kojima, E. Wada, N. Kurosawa, T. Nakaoka, T. Hamamoto, S. Tsuji, J. Biol. Chem. 1994, 269, 10028-10033.

[10] Y.J. Kim, K.S. Kim, S.H. Kim, C.H. Kim, J.H. Ko, I.S. Choe, S. Tsuji, Y.C. Lee,
Biochem. Biophys. Res. Commun. 1996, 228, 324-327.

[11] H. Kitagawa, J.C. Paulson, J. Biol. Chem. 1994, 269, 1394-1401.

[12] a) D.X. Wen, B.D. Livingstone, K.F. Medzihradszky, S. Kelm, A.L. Burlingame, J.C. Paulson, J. Biol. Chem. 1992, 267, 21011-21019; b) H. Kitagawa, J.C. Paulson, Biochem. Biophys. Res. Commun. 1993, 194, 375-382; c) M.A. Williams, H. Kitagawa, A.K. Datta, J.C. Paulson, J. Jamieson, Glycoconjugate J. 1995, 12, 755-761.

[13] a) G. Baisch, R. Öhrlein, M. Streiff, B. Ernst, Bioorg. Med. Chem. Lett. 1996, 6 , 755-758; b) G. Baisch, R. Öhrlein, M. Streiff, Bioorg. Med. Chem. Lett. 1998, 8, 157-160.

[14] O. Schwardt, G.P. Gao, T. Visekrunna, S. Rabbani, E. Gassmann, B. Ernst, J. Carbohydr. Chem. 2004, 23, 1-26.

[15] G. Blatter, J.-M. Beau, J.-C. Jacquinet, Carbohydr. Res. 1994, 260, 189-202.

[16] E.A.L. Biessen, D.M. Beuting, H.C.P.F. Roelen, G.A. van de Marel, J.H. van Boom, T.J.C. van Berkel, J. Med. Chem. 1995, 38, 1538-1546.

[17] a) G.H. Veeneman, S.H. Van Leeuwen, J.H. Van Boom, Tetrahedron Lett. 1990, 31, 1331-1334; b) P. Konradsson, U.E. Udodong, B. Fraser-Reid, Tetrahedron Lett. 1990, 31, 4313-4316.

[18] a) K. Jansson, S. Ahlfors, T. Frejd, J. Kihlberg, G. Magnusson, J. Dahmen, G. Noori, K. Stenvall, J. Org. Chem. 1988, $53,5629-5647$; b) T. Murase, A. Kameyama, K.P.R. Kartha, H. Ishida, M. Kiso, A. Hasegawa, J. Carbohydr. Chem. 1989, 8, 265-283.

[19] P. Fügedi, P.J. Garegg, Carbohydr. Res. 1986, 149, C9-C12.

[20] A. Hasegawa, H. Ohki, T. Nagahama, H. Ishida, M. Kiso, Carbohydr. Res. 1991 , 212, 277-281.

[21] B. Ernst, B. Wagner, G. Baisch, A. Katopodis, T. Winkler, R. Öhrlein, Can. J. Chem. 2000, 78, 891-903.

[22] G. Baisch, R. Öhrlein, M. Streiff, F. Kolbinger, Bioorg. Med. Chem. Lett. 1998, 8 , 751-754.

[23] D.P. Khare, O. Hindsgaul, R.U. Lemieux, Carbohydr. Res. 1985, 136, 285-308.

[24] G. Baisch, R. Öhrlein, B. Ernst, Bioorg. Med. Chem. Lett. 1996, 6, 749-754.

[25] A. Lubineau, C. Augé, P. François, Carbohydr. Res. 1992, 228, 137-144. 